\title{
Aqueous extract of Lannea microcarpa attenuates dextran sulphate- induced paw oedema and xylene-induced ear oedema in rodents
}

\author{
Meshack Antwi-Adjei ${ }^{1 *}$, George Owusu ${ }^{2,3}$, Evans P. K. Ameade ${ }^{2}$
}

${ }^{1}$ Department of Pharmacology, School of Medical Sciences, University of Cape Coast, Cape Coast, Ghana

${ }^{2}$ Department of Pharmacology, School of Medicine and Health Sciences, University for Development Studies, Tamale, Ghana

${ }^{3}$ Department of Pharmacology, Faculty of Pharmacy and Pharmaceutical Sciences, KNUST, Kumasi, Ghana

Received: 01 March 2017 Accepted: 01 April 2017

*Correspondence to: Mr. Meshack Antwi-Adjei, Email: krissnana@yahoo.com

Copyright: (C) the author(s), publisher and licensee Medip Academy. This is an openaccess article distributed under the terms of the Creative Commons Attribution NonCommercial License, which permits unrestricted noncommercial use, distribution, and reproduction in any medium, provided the original work is properly cited.

\begin{abstract}
Background: Lannea microcarpa Engl. and K. Krause (Family Anacardiaceae), a tropical tree is used traditionally used in Africa for both medicinal and non-medicinal purposes. Folkoric uses of the plant include wound healing, conjunctivitis, stomatitis and gingivitis among others. Inflammatory reactions are involved in several diseases which this plant is traditionally used to manage. This study was therefore aimed at investigating the antiinflammatory effects of the aqueous extract of Lannea microcapa.

Methods: Oedema was induced in the right hind paws of Sprague Dawley rats (200-250g, 12 weeks old, $\mathrm{n}=5)$ using dextran sulphate solution whiles ear oedema was induced in ICR mice $(25-30 \mathrm{~g}, 6$ weeks old, $\mathrm{n}=5)$ using xylene solutions. Aqueous extracts of ALM (30, 100 and 300mg kg-1) were administered in a set of rats and mice for both prophylactic and therapeutic studies. In the dextran sulphate-induced paw oedema, rats (200-250g) were treated orally with ALM $(30,100$ and $300 \mathrm{mg} \mathrm{kg}-1)$ for both prophylactic and therapeutic studies. The paw thickness of the rats was measured before and after dextran sulphate injection at an hourly interval for $5 \mathrm{~h}$. For xylene-induced ear oedema, ICR mice $(25-30 \mathrm{~g})$ were given the same doses of the ALM and the ear weight of mice were measured after $2 \mathrm{~h}$.

Results: In the dextran sulphate-induced paw oedema, the ALM reduced the mean maximal paw oedema significantly $(\mathrm{P} \leq 0.05)$ to $36.392 \pm 9.207 \%$ and $26.050 \pm 3.396 \%$ at 100 and $300 \mathrm{mg} \mathrm{kg}^{-1}$ (prophylaxis) and $32.192 \pm 5.670 \%$, $31.398 \pm 6.921 \%$ and $31.593 \pm 5.841 \%$ at 30,100 and $300 \mathrm{mg} \mathrm{kg}-1$ (therapeutic) in dose dependent manner when compared to the control respectively. Similarly, the ALM dose dependently showed a significant $(\mathrm{P} \leq 0.05)$ reduction of percentage mean oedema in xylene-induced ear oedema by $43.56 \%, 59.63 \%$ and $68.07 \%$ at 30,100 and $300 \mathrm{mg} \mathrm{kg}^{-1}$ when compared to the control respectively.

Conclusions: Aqueous extract of Lannea microcapa (30 -300 mg kg-1) caused significant reduction of oedema in both dextran sulphate-induced paw oedema and xylene-induced ear oedema.
\end{abstract}

Keywords: Anti-inflammation, Dextran sulphate, Lannea microcarpa, Oedema, Xylene

\section{INTRODUCTION}

Inflammatory response is usually stimulated by the action of various immune capable cells such as lymphocytes, platelets, mast cells and macrophages. Mast cells play a key role in the generation of inflammation via the release of inflammatory mediators including preformed soluble mediators such as histamine and serotonin. ${ }^{1,2}$ Others include metabolites of arachidonic acid metabolism, proinflammatory cytokines and chemokines which cause inflammation and further act to enhance inflammatory response. ${ }^{3}$ Pharmacological intervention is therefore required to regulate the activities of these inflammatory responses and also to manage their effects. Conventional drugs used in the management of inflammation include non-steroidal antiinflammatory drugs (NSAIDs), glucocorticoids and the disease modifying antirheumatic drugs. ${ }^{4}$ These drugs have been reported to be associated with numerous adverse effects and therefore natural products such as plants are being considered as 
alternative source of pharmacological remedy of inflammation. One of such plants is Lannea microcarpa Engl. and K. Krause (Family Anacardiaceae), a deciduous tree of the savannah, that grows up to about 15 $\mathrm{m}$ tall and $70 \mathrm{~cm}$ in diameter. It is located in most regions of West Africa and largely distributed in the dry forest regrowth areas. The leaves usually alternate and imparipinnate up to about $25 \mathrm{~cm}$ long with two to three pairs of leaflets. The flowers are green-yellowish, unisexual and regular; and the fruits are ellipsoid and glabrous drupes containing a single seed..$^{5}$ Most parts of Lannea microcarpa such as the bark and leaves are used traditionally in treating numerous medical disorders including swellings, gonorrhea, respiratory disorders, blisters, sore throat and rheumatism. ${ }^{5-9}$ It has also been reported to possess wound healing ability, antimalarial, antidiarrheal, antigastroenteritis, cutaneous antiirritating effects as well as antibacterial and antihypertensive effects. ${ }^{10-18}$ Quantitative determination of phytochemical composition of the plant has been reported and this revealed the presence of numerous phytochemical constituents. ${ }^{14,18-21}$ Due to these numerous positive reports on this plant, it is therefore imperative that we carry out a scientific research on the antiinflammatory effect of aqueous extract of this time tested plant to provide a valid scientific data to support its traditional uses.

\section{METHODS}

\section{Plant collection}

The stem bark of Lannea microcarpa was collected from New Edubiase, Ashanti Region of Ghana in April, 2016 and it was authenticated by Dr. Henry Sam of the Department of Herbal Medicine, Kwame Nkrumah University of Science and Technology, Kumasi, Ghana. The plant material was chopped and air-dried for 14 days under room temperature.

\section{Extraction}

The chopped stem bark was milled into coarse powder using a hammer mill (DF-19, DADE, $20 \mathrm{~kg} / \mathrm{h}-101 \mathrm{v}$, HXJQ, China). Six hundred grams $(600 \mathrm{~g})$ of the powder was mixed with $2.0 \mathrm{~L}$ of water and warmed for $90 \mathrm{~min}$ at $90{ }^{\circ} \mathrm{C}$. The mixture was filtered to obtain a dark-brown filtrate which was evaporated over a hot water-bath followed by drying in an oven at $60^{\circ} \mathrm{C}$. The final concentrate was cooled in a desiccator for 60 minutes to yield a dark-brown semi-solid Lannea microcarpa extract (refer to as ALM). The final yield was $12.4 \%$. The extract was reconstituted as an emulsion in $2 \%$ tragacanth mucilage.

\section{Chemicals}

Dextran sulphate powder (Sigma-Aldrich, St. Louis, MO, USA), Diclofenac (Trogue, Hamburg, Germany), xylene solution (Shire Pharmaceuticals Inc., MA, USA).

\section{Animals}

Sprague Dawley rats (200-250g) and ICR (Imprint Control Region) mice $(25-30 \mathrm{~g})$ were purchased from Centre for Scientific Research into Plant Medicine, Mampong-Akropong, Ghana. The animals were grouped into treatment and control groups $(\mathrm{n}=5)$; and kept in stainless steel cages $(34 \mathrm{~cm} \times 47 \mathrm{~cm} \times 18 \mathrm{~cm})$ in the animal house of Department of Pharmacology, KNUST. The animals were maintained at a room temperature of $26 \pm 27^{\circ} \mathrm{C}$ and incandescent illumination was provided on 12-h light-dark cycle. The animals were fed with commercial diet (GAFCO, Tema, Ghana) and water ad libitum. The animals were ethically handled throughout the experiment in consonant with internationally accepted principles for laboratory animals' use and care (EEC Directive of 1986: 86/609 EEC). Also, all animals and inflammatory protocols used in the experiment were approved by the Department of Pharmacology, KNUST Ethics Committee. Each animal was used only once and at the end of each experiment animals were euthanized.

\section{Phytochemical analysis}

The aqueous extract was analyzed using simple qualitative analysis previously described..$^{22}$

\section{Dextran sulphate-induced paw oedema}

Paw oedema was induced by a method previously described. $^{23}$ Briefly, $0.1 \mathrm{ml}$ of $1 \%(\mathrm{~W} / \mathrm{v})$ dextran sulphate dissolved in saline solution was injected into the subplantar region of the right hind paw of rats (200$250 \mathrm{~g}$ ). The paw thickness was measured before oedema induction and then at hourly intervals for $5 \mathrm{~h}$ post injection using a digital caliper (VC1346i, MP Lab Equip, U.S.A). Increase in paw thickness was expressed as the mean percentage change of paw thickness using the formula:

$\%$ change in paw thickness $=\left[\frac{\mathrm{PT} o-\mathrm{PT} t}{\mathrm{PT} o}\right] \times 100$

Where PT $t$ is the Paw thickness (at various time points) post dextran sulphate injection and PTo is the Paw thickness before dextran sulphate injection. Total oedema was determined as the area under the time course curve (AUC) during the $5 \mathrm{~h}$ of dextran sulphate injection. The percentage inhibition of the total oedema was calculated using the formula

$\%$ Inhibition of edema $=\left[\frac{\text { AUC control-AUC treated }}{A U C \text { control }}\right] \times 100$

In the prophylactic protocol, the test animals were treated with $\operatorname{ALM}\left(30,100,300 \mathrm{mg} \mathrm{kg}^{-1}, 1 \mathrm{~h}, \mathrm{p} . \mathrm{o}\right)$ or diclofenac (30 mg kg-1, $30 \mathrm{~min}$, i.p) before dextran sulphate injection. In the therapeutic protocol, drugs were administered $1 \mathrm{~h}$ post subplantar injection of dextran sulphate. Control rats received $1 \mathrm{ml}$ of normal saline. 


\section{Xylene-induced ear oedema}

Ear oedema was induced by a method earlier described ${ }^{24}$ with slight modification. Briefly, $0.03 \mathrm{ml}(50 \mu \mathrm{l})$ of xylene solution was topically applied on both posterior and anterior surfaces of the right ear. Mice (25-30g) in test groups (I, II and III) were treated with a single dose of $\operatorname{ALM~}\left(30,100\right.$ and $300 \mathrm{mg} \mathrm{kg}^{-1}$, p.o, $1 \mathrm{~h}$ ) and groups (IV, $\mathrm{V}$ and $\mathrm{VI})$ received a single dose of diclofenac $(1,10$ and $30 \mathrm{mg} \mathrm{kg}^{-1}$, i.p, $30 \mathrm{~min}$ ) post xylene injection over an experimental period of $2 \mathrm{~h}$. The left ear was used as a control. The mice were sacrificed after $2 \mathrm{~h}$ by cervical dislocation and the ears (left and right) were excised and weighed on an electronic balance (Model: XPE10001L, METTLER TOLEDO, Switzerland). The degree of ear oedema was determined as the percentage difference between the right and left ears.

\section{Determination of EDs0}

$\mathrm{ED}_{50}$ (dose responsible for $50 \%$ of maximal effect) was determined for the Lannea microcarpa extract (30, 100 and $300 \mathrm{mg} \mathrm{kg}^{-1}$ ) in the xylene-induced ear oedema model.

\section{Statistical analysis}

Data obtained was presented as mean \pm SEM. Statistical analysis was done by using one-way analysis of variance (ANOVA) followed by Bonferroni's post hoc test. GraphPad Prism for Windows, Version 6 (GraphPad Software, San Diego, CA, USA) was used for all statistical analyses. Probabilities less than $0.05(\mathrm{P} \leq 0.05)$ was considered statistically significant between means of treated groups and the control. The ED50 (dose responsible for $50 \%$ of maximal effect) was determined by using an iterative computer least square method, with the non-linear regression (three-parameter logistic) equation.

$$
Y=\frac{a+(b-c)}{\left(1+10^{\left(\log E D_{50}-X\right)}\right)}
$$

Where $\mathrm{X}$ is the logarithm of dose and $\mathrm{Y}$ is the response. $\mathrm{Y}$ begins at a (the bottom) and goes to $\mathrm{b}$ (the top) with $\mathrm{a}$ sigmoid shape.

\section{RESULTS}

\section{Phytochemical analysis}

Qualitative phytochemical constituents test revealed the presence of steroids, glycosides, tannins, saponins, triterpenoids, alkaloids, and flavonoids.

\section{Dextran sulphate-induced paw oedema}

Injection of dextran sulphate $(0.1 \mathrm{ml}$ of $1 \%$ in saline $)$ resulted in paw swelling of the hind paw of the rats peaking between 2-3 h. ALM administered pre-emptively reduced the mean maximal oedema significantly to $36.392 \pm 9.207 \%$ and $26.050 \pm 3.396 \%$ at 100 and $300 \mathrm{mg}$ $\mathrm{kg}^{-1}$ respectively (Figure 1A) when compared to the inflamed control response $(73.607 \pm 4.990 \%)$ while the total paw oedema induced over $5 \mathrm{~h}$ (measured as the area under the time course curve, AUC) was also significantly $(\mathrm{P} \leq 0.05)$ reduced by $40.93 \pm 13.83 \%$ and $64.17 \pm 5.738 \%$ at 100 and $300 \mathrm{mg} \mathrm{kg}^{-1}$ in a dose dependent manner (Figure 1B) when compared to the inflamed control response $(264.7 \pm 10.94 \%)$.
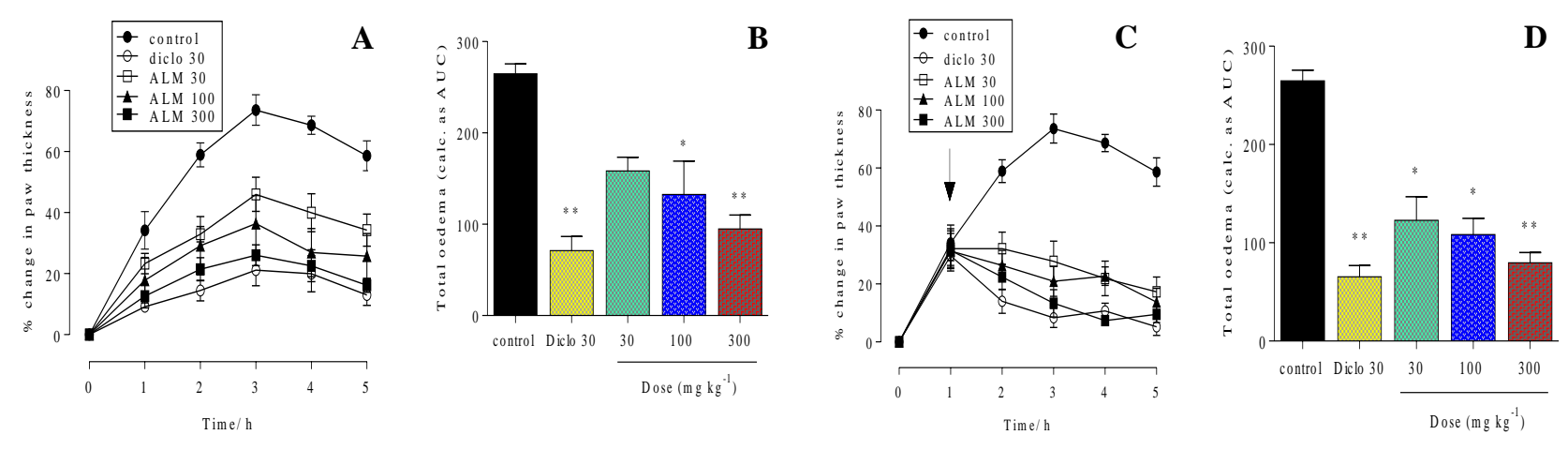

Figure 1: Effect of Lannea microcarpa extract on the maximal (A and C) and the total oedema responses (B and D) in the prophylactic and therapeutic studies of dextran sulphate-induced paw oedema in rats respectively $(n=5) . \downarrow$ denotes time of drug administration.

The same doses of ALM (30, 100 and $300 \mathrm{mg} \mathrm{kg}^{-1}$ ) administered after dextran sulphate paw oedema induction (therapeutic) reduced the mean maximal paw oedema to $32.192 \pm 5.670 \%, \quad 31.398 \pm 6.921 \%$ and $31.593 \pm 5.841 \%$ at 30,100 and $300 \mathrm{mg} \mathrm{kg}^{-1}$ respectively when compared to the control inflamed response of $73.607 \pm 4.990 \%$ (Figure $1 \mathrm{C}$ ). The total paw oedema induced over $5 \mathrm{~h}$ was also reduced significantly $(\mathrm{P} \leq 0.05)$ by $53.61 \pm 9.126 \%, 59.09 \pm 6.220 \%$ and $69.97 \pm 4.028 \%$ at 30, 100 and $300 \mathrm{mg} \mathrm{kg}^{-1}$ (Figure 1 D) when compared to 
the inflamed control response. Diclofenac (30 $\left.\mathrm{mg} \mathrm{kg}^{-1}\right)$, the reference drug used, significantly suppressed all the parameters evaluated (Figure 1 A-D).

\section{Xylene-induced ear oedema}

$\operatorname{ALM}\left(30,100\right.$ and $300 \mathrm{mg} \mathrm{kg}^{-1}$, p.o) administered before the induction of xylene ear oedema caused the mean percentage ear oedema to be reduced significantly ( $\mathrm{P}$ $\leq 0.05)$ by $43.56 \pm 9.183 \%, \quad 59.63 \pm 13.500 \%$ and $68.07 \pm 14.98 \%$ at 30,100 and $300 \mathrm{mg} \mathrm{kg}^{-1}$ respectively when compared with the inflamed control response of $82.33 \pm 11.77 \%$ (Figure 2 B). Diclofenac (1-30 mg kg-1), the reference drug used, suppressed the mean percentage ear oedema significantly (Figure $2 \mathrm{~A}$ ).

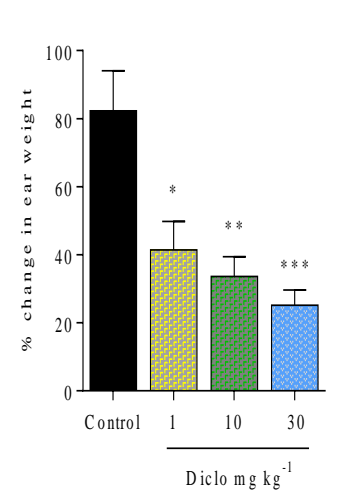

A

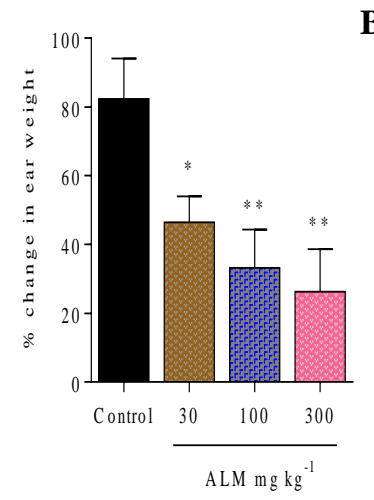

Figure 2: Effect of Lannea microcarpa extract on the total oedema responses $(B)$ in xylene-induced ear oedema in mice respectively $(n=5)$.

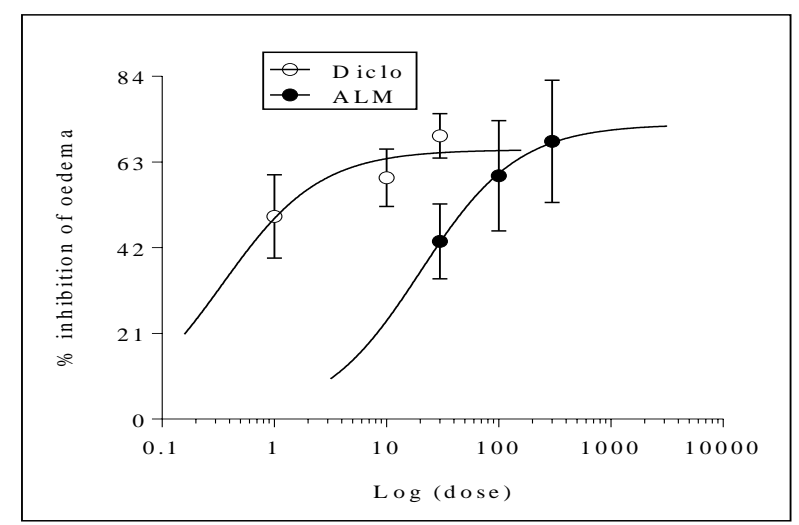

Figure 3: Dose response curves for Lannea microcarpa extract (30, 100 and $300 \mathrm{mg} \mathrm{kg}-1)$ and diclofenac (1, 10 and $30 \mathrm{mg} \mathrm{kg-1)}$ in xylene-induced ear edema in mice $(n=5)$.

\section{$\mathrm{ED}_{50}$ for Lannea microcarpa extract (ALM)}

Dose response curves for percentage inhibition of oedema is shown in Figure 3. ALM displayed a sigmoidal curve dose response relation with $\mathrm{ED}_{50}$ of $20.04 \pm 2.71$ whiles the $\mathrm{ED}_{50}$ for diclofenac was $2.13 \pm 0.344$.

\section{DISCUSSION}

In this study, the aqueous extract of the stem bark of Lannea microcarpa was considered as a potential agent for antiinflammatory activity based on its folkloric use in traditional medicine for treatment of pain, wound, swelling and other many medical disorders. Phytochemical constituents such as steroids, glycosides, tannins, saponins, triterpenoids, alkaloids, and flavonoids were present in the extract of the stem bark of Lannea microcarpa which is in consonant with the earlier phytochemical screening conducted..$^{14,16,18-20}$ In this study, dextran sulphate injected in the rats induces anaphylactic reaction characterized by extravasation and oedema formation as a result of histamine and serotonin release from the mast cells. ${ }^{25}$ Dextran is known to be a potent osmotic agent which causes significant increase in vascular permeability and blood flow to the inflammatory site. ${ }^{26}$ Oedema formation is usually caused by certain mediators such as prostaglandins, nitric oxide, histamine, serotonin and bradykinin due to the activity of cyclooxygenase enzyme. ${ }^{27}$ The inhibition of these proinflammatory mediators provides a competent pharmacological remedy to inflammatory disorders. In the present study, Lannea microcarpa extract (ALM) administered either before or after dextran sulphate paw oedema induction inhibited the activities of histamine, bradykinin and serotonin during inflammatory response. It is therefore not surprising that the extract induced a more potent reduction of oedema formation and suppressed cyclooxygenase activity hence reducing the synthesis of prostaglandins and other proinflammatory mediators.

Xylene-induced ear oedema is widely employed in screening antiinflammatory agents capable of altering the activity of phospholipase $A_{2}$ enzyme. ${ }^{28}$ Xylene usually initiates inflammatory response resulting in oedema, warmth and redness of the skin of the ear of mice due to the release of histamine, kinin, fibrinolysin and substance P. ${ }^{29-32}$ In this investigation, Lannea microcarpa extract (ALM) significantly inhibited xylene-induced ear oedema in a dose related manner and ultimately decreased irritation, oedema and erythema effects and so it could be suggested that the extract inhibited the activities of the proinflammatory mediators including histamine, kinins and fibrinolysin. Although the actual mechanism of action of Lannea microcarpa extract (ALM) was not demonstrated in this research, its anti-inflammatory effects may be attributed to one or more of the phytochemicals constituents such as flavonoids, steroids saponins and tannins which were found to be present in the extract. From the study, it could be deduced that the effective dose of maximal inhibition for Lannea microcarpa extract (ALM) was higher than diclofenac which indicated relatively less potency when compared to diclofenac. 


\section{CONCLUSION}

We therefore conclude that aqueous extract of the stem bark of Lannea microcarpa possesses antiinflammatory effect on acute inflammation mediated through the inhibition of proinflammatory mediators such as histamine, serotonin and other cytoplasmic enzymes.

\section{ACKNOWLEDGEMENTS}

We thank Gordon Darku, the Principal Technician of the Department of Pharmacology, KNUST and other technical staffs for their support in carrying out this research.

\section{Funding: No funding sources}

Conflict of interest: None declared

Ethical approval: The study was approved by the Institutional Ethics Committee

\section{REFERENCES}

1. Lundequist A, Pejler G. Biological implication of preformed mast cell mediators. Cell Mol Life Sci. 2011;68:965-75.

2. Awortwe C, Osei-Sarfo D, Asiedu-Gyekye IJ, Sackeyfio AC. The anti-inflammatory activity of Taraxacum officinale leaves in ovalbumin-sensitized guinea pigs. Int J Pharm Pharm Sci. 2013;5(2):62833.

3. Goldsby RA, Kindt TJ, Osbourne BA, Kuby J. Immunology. 4th ed. New York, NY:WII Freeman; 2000:328.

4. Bansod MS, Kagathara VG, Pujari RR, Patel VB, Ardeshna HH. Therapeutic effects of A-polyherbal preparation on Adjuvant-induced arthritis in Wistar rats. Int. J Pharm Pharm Sci. 2011;3(2):186-92.

5. Marquet M, Jansen PCM. Lannea microcarpa Engl. and $K$. Krause. Record from PROTA4U. Jansen, P.C.M. \& Cardon, D. PROTA, 2005 (Plant Resources of Tropical Africa / Ressources végétales de l'Afrique tropicale), Wageningen, Netherlands. Available from<http://www.prota4u.org/search.asp >.

6. Burkill HM. The useful plants of West Tropical Africa. 2nd Ed. Families S-Z, Addenda. Royal Botanic Gardens, Kew, Richmond, United Kingdom. 2000;5:686.

7. Kamanzi AK, Schmid C, Brun R, Kone MW, Troare D. Antitrypanosomal and antiplasmodial acyivity of medicinal plants from Cote d'Ivoire. J. Enthnopharmacol. 2004;90:221-7.

8. Koné WM, Atindehou KK, Terreaux C, Hostettmann K, Traoré D, Dosso M. Traditional medicine in North Côte d'Ivoire: screening of 50 medicinal plants for antibacterial activity. J Ethnopharmacol 2004;93(1):43-9.

9. Chabi China TF, Olounladé PA, Salifou S. Ethnobotanical study of endogenous methods used for the treatment of diseases of Somba cattle breed in northen Benin. J Drug Deliv Therapeu. 2014;4(3):87105.

10. Inngjerdongen K, Nergård CS, Diallo D, Mounkoro PP, Paulsen BS. An ethnopharmacological survey of plants used for wound healing in Dogonland, Mali, West Africa. J Ethnopharmacol. 2004;92:233-44.

11. Nacoulma OG. Medicinal Plant and traditional practices in Burkina Faso: The case of the central plateau. Ph.D. Thesis in Nat Sci. 1996;1:2.

12. Arbonnier M. Trees, shrubs and lianas of West African dry zones. CIRAD, Margraf Publishers Gmbh, MNHN, Paris, France;2004:573.

13. Tapsoba H, Deschamps JP. Use of medicinal plants for the treatment of oral diseases in Burkina Faso. J. Ethnopharmacol. 2006;104:68-78.

14. Picerno P, Mencherini T, Della-Loggia R, Meloni M, Sanogo R. An extract of Lannea microcarpa: composition, activity and evaluation of cutaneous irritation in cell cultures and reconstituted human epidermis. J Pharm Pharmacol. 2006;58(7):981-8.

15. Lamien-Meda A, Lamien CE, Compaoré MMY, Meda NT, Kiendrebeogo M, Zeba B et al. Polyphenol content and antioxidant activity of fourteen wild edible fruits from Burkina faso. Molecules. 2008;1420-8049.

16. Ouattara L, Koudou J, Zongo C, Barro N, Sawadogo A, Bassole IHN et al. Antioxidant and antibacterial activities of three species of Lannea from Burkina Faso. J Appl Sci. 2011;11(2):157-62.

17. Ouedraogo S, Belemnaba L, Zague H, Traore A, Lompo M, Guissou IP et al. Endothelium independent vasorelation by extract and fractions from Lannea microcarpa Engl. and $K$. Krause (Anacardiaceae): Possible involvement of phosphodiesterase inhibition. Int. J Phamacol Biol Sci. 2010;4(2):9-16.

18. Bationo BA, Ouedraogo SJ, Guinko S. Longévité des graines et contraintes à la survie des plantules d'AFZELIA africana Sm. dans une savane boisée du Burkina Faso. Annal Forest Sci. 2001;58(1):69-75.

19. Duponchel P. Textiles bògòlan du Mali. Collections du Mali No. 8. Musée d'Ethnographie, Neuchâtel, Switzerland. 2004:334.

20. Ajiboye TO, Rajib HO, Muritalac HF, Ojewuyia OB, Yakubuc MT. Anthocyanin extract of Lannea microcarpa fruits stall oxidative rout associated with aflatoxin B1 hepatocarcinogenesis. Food Biosci. 2013;4:58-67.

21. Yunus MM, Zuru AA, Faruq UZ, Aliero AA. Assessment of Physicochemical of Biodiesel from African Grapes (Lannea microcarpa Engl. \& K. Krause). Nig J Basic Appl Sci. 2013;21(2):127-30.

22. Trease GE, Evans WC. Textbook of Pharmacognosy. 13th Edn. Balliere Tindall, London;1989:409-91.

23. Winter CA, Risley EA, Nuss GW. Carrageenaninduced edema in hind paw of rats as an assay for antiinflammatory drugs. Proceedings Soc Experiment Biol Med. 1962;111:544-7. 
24. Tang X, Lin Z, Cai W, Chen N, Shen L. Antiinflammatory effect of 3-Acethylaconitine. Acta Pharmacol Sin. 1984;5:85-9.

25. Van Wauve JP, Goosens JG. Arabinolactan and dextran-induced ear inflammation in mice: differential inhibition by $\mathrm{H} 1$-antihistamines, 5-HTserotonin antagonists and lipooxygenase blockers. Agents Action. 1989;28:78-82.

26. Lo TN, Almeida AP, Beaven MA. Dextran and carrageenan evoke different inflammatory response in rat with respect to composition of infiltrates and effect of indomethacin. J Pharmacol Experiment Therapeu. 1982;221:261-7.

27. De Araújo IWF, De Sousa OVE, Rodrigues JAG, Coura CO, Quinderé ALG, Fontes BP et al. Effects of a sulfated polysaccharide isolated from the red seaweed Solieria filiformis on models of nociception and inflammation. Carbohydr Polym. 2011;86:1207-15.

28. Ndebia EJ, Umapathy E, Nkeh-Chungag BN, Iputo JE. Antiinflammatory properties of Albuca setosa and its possible mechanism of action. J Med Plants Res. 2011;5:4658-64.
29. De La Puerta R, Martinez E, Bravo L, Ahumada MC. Effect of silymarin on different acute inflammation models and on leukocyte migration. J Pharm Pharmacol. 1996;48(9):968-970.

30. Kim HD, Cho HR, Moon SB, Shin HD, Yang KJ, Park BR. et al. Effects of beta-glucan from Aureobasidium Pullulans on acute inflammation in mice. Arch Pharm Res. 2007;30:323-8.

31. Cho KH, Kim HD, Lee BW, Lim MK, Ku SK. Effects of magnetic infrared laser on xylene-induced acute inflammation in mice. J Phys Therapy Sci. 2008;20(4):255-9.

32. Li YC, Xian YF, Ip SP, Su Zi R, Su Ji Y, He JJ et al. Anti-inflammatory activity of patchouli alcohol isolated from Pogostemonis Herba in animal models. Fitoterapia. 2011;82:1295-301.

Cite this article as: Antwi-Adjei M, Owusu G, Ameade EPK. Aqueous extract of Lannea microcarpa attenuates dextran sulphate-induced paw oedema and xylene-induced ear oedema in rodents. Int J Basic Clin Pharmacol 2017;6:1048-53. 